\title{
PENGARUH MODEL DAN MEDIA PEMBELAJARAN TERHADAP HASIL BELAJAR KEMAMPUAN DASAR SENAM LANTAI PADA MAHASISWA JURUSAN PENJASKESREK UNDIKSHA
}

\author{
Luh Putu Spyana Wati ${ }^{1}$, Kadek Yogi Parta Lesmana² \\ 1,2Pendidikan Jasmani Kesehatan dan Rekreasi, Universitas Pendidikan \\ Ganesha, Indonesia \\ E-mail:spyana@yahoo.com
}

\begin{abstract}
Abstrak
Penelitian ini bertujuan (1) menjelaskan perbedaan hasil belajar kemampuan dasar senam lantai yang signifikan antara model pembelajaran Think-Pair-Share (TPS) dengan model pembelajaran Student Teams-Achievement Devision (STAD). (2) menjelaskan perbedaan hasil belajar kemampuan dasar senam lantai antara mahasiswa yang belajar dengan media VCD dan media gambar. (3) menjelaskan pengaruh interaktif antara model dan media pembelajaran terhadap hasil belajar. Penelitian ini adalah penelitian eksperimen semu (quasi experiment) menggunakan pretest-posttest non-equivalent control group design.Populasi penelitian berjumlah 6 kelas yang terdiri dari 156 mahasiswa. Sampel diambil 4 kelas dengan cara simple random sampling. Data dikumpulkan dengan tes hasil belajar dan dianalisis dengan ANACOVA faktorial $2 \times 2$. Hasil penelitian menunjukkan bahwa, (1) terdapat perbedaan hasil belajar kemampuan dasar senam lantai yang signifikan antara model pembelajaran Think-Pair-Share (TPS) dengan model pembelajaran Student Teams-Achievement Devision (STAD) (F = 64.805; $p<0.05)$, dimana hasil belajar kemampuan dasar senam lantai pada mahasiswa yang mengikuti model pembelajaran Think-Pair-Share (TPS) lebih baik dibandingkan dengan mahasiswa yang mengikuti model pembelajaran Student Teams-Achievement Devision (STAD), (2) terdapat perbedaan hasil belajar yang signifikan antara media pembelajaran VCD dengan media pembelajaran gambar terbukti pada nilai $(F=52.577 ; p<0.05)$, (3) terdapat pengaruh interaktif antara media dan model pembelajaran terhadap hasil belajar kemampuan dasar senam lantai terbukti pada nilai $(F=88.185 ; p<0.005)$.
\end{abstract}

Kata kunci: Model Pembelajaran, Media pembelajaran, Hasil Belajar

\begin{abstract}
This study aims to (1) explain the differences in learning outcomes of basic capabilities floor exercises significant between learning model Think-Pair-Share (TPS) learning model Student Teams-Achievement Devision (STAD). (2) explain the differences in learning outcomes between the floor exercise basic abilities of students studying with VCD media and media images. (3) describes the interactive effects between model and learning media on learning outcomes. This study is a quasi-experimental research (quasi experiment) using a pretest-posttest non-
\end{abstract}


equivalent control group design.Populasi study amounted to 6 classes of 156 students. Samples were taken 4 classes by simple random sampling. Data collected by achievement test and analyzed with the $2 \times 2$ factorial ANACOVA. The results showed that, (1) there are differences in learning outcomes of basic capabilities floor exercises significant between learning model Think-Pair-Share (TPS) learning model Student Teams-Achievement Devision (STAD) (F = 64 805; $p<0.05)$, where the learning outcomes of basic capabilities gymnastics floor on students who attend learning model Think-Pair-Share (TPS) is better than the students who attend the learning model student Teams-Achievement Devision (STAD), (2) there are differences in learning outcomes significantly between media learning VCD with instructional media images proved the value $(F=52577 ; p$ $<0.05)$, (3) there are interactive effects between media and learning model for learning outcomes of basic capabilities gymnastics floor proved the value ( $F=88$ $185 ; \mathrm{p}<0.005)$.

Keywords: Learning Model, Media Learning, Learning Outcomes

\section{PENDAHULUAN}

Seiring

dengan

pesatnya perkembangan ilmu pengetahuan dan teknologi dituntut pula peningkatan kualitas pendidikan untuk mengimbanginnya, sehingga menghasilkan sumber daya manusia (SDM) yang berkualitas dan siap bersaing dengan bangsa-bangsa lain untuk menguasai teknologi. Akan tetapi kenyataanya yang dapat kita jumpai saat ini pendidikan di Indonesia masih ketinggalan untuk mengimbanginnya. Hal ini disebabkan oleh berbagai hal, antara lain rendahnya kualitas pendidikan saat ini. Sebenarnya pihak pemerintah telah mengupayakan untuk meningkatkan kualitas pendidikan yang meliputi peningkatan kualitas edukatif, system kurikulum maupun sarana. Mengingat adanya keterbatasan kemampuan pemerintah khususnya dalam hal sarana pendidikan, maka perlu adanya langkah kreatif dan inovatif untuk menyiasatinya dengan melaksanakan proses pembelajaran yang variatif sesuai dengan lingkungan dan kebutuhan masing-masing.
Penggunaan alat bantu atau media pembelajaran diharapkan dapat mengoptimalkan proses pembelajaran di dalam kelas maupun di luar kelas. Media pembelajaran dapat memotivasi mahasiswa untuk belajar dengan senang yang akhirnya dapat meningkatkan hasil belajar mahasiswa.

\section{Enggen dan Kauchak (dalam} Aisyah 2008) menyatakan pembelajaran akan efektif apabila siswa/mahasiswa secara aktif terlibat dalam pengorganisasian dan penemuan informasi (pengetahuan). Menurut Isjoni (2009), pembelajaran adalah sesuatu yang dilakukan oleh siswa/mahasiswa, bukan dibuat untuk siswa/mahasiswa. Pembelajaran pada dasarnya merupakan upaya pendidik untuk membantu peserta didik melakukan kegiatan belajar.Pendidikan jasmani, olahraga dan kesehatan adalah proses pendidikan yang memanfaatkan aktivitas jasmani yang direncanakan secara sistematik, terencana, dan terarah yang bertujuan untuk mengembangkan dan meningkatkan individu secara organik, neuromuscular, perseptual, kognitif, dan emosional, 
dalam kerangka sistem pendidikan nasional. Selain itu, program Pendidikan Jasmani sebaiknya memberi kesempatan bagi semua siswa/mahasiswa untuk meningkatkan dan mempertahankan kesegaran jasmani, sepadan dengan kebutuhan individual. Usaha meningkatkan kesegaran jasmani secara keseluruhan, meliputi kesehatan; berat badan yang sesuai, usia, jenis kelamin, kemampuan motorik umum,

kesehatan kardiorespiratori, ketangkasan neuromuskular. Menurut Wixon dan Jewett (dalam Abdullah \& Munadji, 1994), pendidikan jasmani adalah satu tahap atau aspek dari proses pendidikan keseluruhan yang berkenaan dengan perkembengan dan penggunaan kemampuan gerak individu yang dilakukan atas kemauan sendiri serta bermanfaat dan dengan reaksi atau respon yang terkait langsung dengan mental, emosi, dan sosial.

Bagi guru/dosen penentuan model pembelajaran menjadi tugas utama sehingga mampu menciptakan pembelajaran yang bermanfaat dan bermakna (meaningfull learner). Banyaknya model pembelajaran yang ada akhir-akhir ini tidak menjamin akurasi terhadap karakteristik bidang studi, peserta didik dan lingkungan pembelajarannya. Oleh karena itu pemilihan yang mampu menyesuaikan dengan karakteristik tersebut menjadi keniscayaan. Seperti yang diungkapakan oleh Husdarta (2009) tentang pembelajaran Penjasorkes, bahwa seorang pendidik kurang memperhatikan kemampuan dan kebutuhan peserta didik dalam melaksanakan pendidikan jasmani, penerapan tahapan penyajian tugas gerak yang disesuaikan dengan kemampuan anak kurang diperhatikan. Hal ini akan berdampak pada rendahnyan kualitas pembelajaran serta kualitas penguasaan peserta didik.

Keberhasilan proses dalam pembelajaran pendidikan jasmani, olahraga dan kesehatanditentukan oleh banyak faktor antara lain: model pembelajaran, guru, saranaprasarana,dan situasi dalam proses belajar mengajar. Para pakar pendidikan telah banyak mengadakan terobosan tentang model pembelajaran yang telah diujicobakan, namun sampai sekarang belum bisa dipastikan mana yang paling tepat dipergunakan karena dalam proses pembelajaran sangat tergantung pada aktivitas siswa itu sendiri.

Berdasarkan pengalaman yang diperoleh di dalam mengajar mata kuliah praktek ditemukan berbagai kesulitan terutama dalam mengubah prilaku yang telah dimiliki oleh peserta didik, mengarahkan perhatian yang fokus pada peserta didik, serta mengembangkan reaksi emosional yang positif bagi peserta didik. Hal ini cukup berdampak pada kualitas pembelajaran yang dilakukan sehingga hasil belajarnya pun akan berpengaruh secara signifikan. Ditinjau dari hasil ujian praktek pada mata kuliah senam lantai selama dua tahun terakhir dari tahun 2010 sampai dengan 2012 diperoleh rincian sebagai berikut: dari 173 mahasiswa, hanya 16 orang $(9 \%)$ memperoleh nilai A, 80 orang (46\%) memperoleh nilai $B, 68$ orang $(39 \%)$ memperoleh nilai $\mathrm{C}$ dan 1 orang $(0,5 \%)$ memperoleh nilai $D$, hal ini dapat disimpulkan bahwa nilai akhir mahasiswa masih terbanyak pada nilai $B$ dan $C$, hanya sebagian kecil 
memperoleh nilai A dan ada pula yang tidak lulus (nilai D), frekuensi nilai ini harus ditingkatkan ke arah perolehan nilai $A$ dan $B$. Hal ini besar kemungkinan disebabkan oleh penerapan model pembelajaran yang tidak mampu mengakomodir seluruh perbedaan kemampuan fisik (skill) dan emosional yang dimiliki mahasiswa.

Saat ini model pembelajaran yang ada sangat beragam, namun salah satu yang menjadi perhatian adalah model kooperatif Think-Pair-Share dan model pembelajaran kooperatif tipe STAD (Student Teams-Achievement Devision). Berdasarkan kajian yang dilakukan, model pembelajaran kooperatif mampu mengubah asumsi bahwa metode resitasi dan diskusi perlu diselenggarakan dalam setting kelompok kelas secara keseluruhan. Metode Think-Pair-Share memberikan kepada para mahasiswa untuk berpikir dan merespon serta saling bantu satu sama yang lainnya.

TPS adalah sebuah metode dimana siswa duduk berpasangan dengan kelompoknya, guru memberikan pertanyaan di kelas, lalu siswa diperintahkan untuk memikirkan jawaban, kemudian siswa berpasangan dengan masing-masing pasangannya untuk mencari kesepakatan jawaban. Terakhir guru meminta siswa untuk membagi jawaban kepada seluruh siswa di kelas (Slavin, 1990).

$$
\text { Model pembelajaran ini }
$$

memberikan kesempatan kepada siswa untuk bekerja sendiri dan bekerjasama dengan orang lain. Suprijono (dalam Thobroni \& Mustofa, 2011) memaknai model pembelajaran Think Pair Share terdiri dari Tahap thinking yaitu pada tahap ini siswa memikirkan sendiri jawaban dari permasalahan yang diberikan oleh guru, lalu yang kedua adalah tahap pairing pada tahap ini siswa mendiskusikan jawaban yang telah mereka pikirkan dengan teman sebangku untuk mendapatkan satu jawaban yang disepakati bersama, dan tahap yang ketiga adalah tahap sharing yaitu masing-masing kelompok/ pasangan mempresentasikan hasil diskusi/jawaban dari permasalahan yang telah disepakati bersama. Sedangkan Trianto (2010) menyebutkan langkah-langkah model pembelajaran think pair share terdiri dari 5 langkah yaitu tahap pendahulua, think, pair, share dan yang terakhir adalah tahap penghargaan.

Menurut Lie (2002), model pembelajaran think pair share memiliki beberapa keunggulan yaitu mampu mengoptimalkan partisipasi siswa di dalam pembelajaran, siswa dapat bekerja sendiri sekaligus bekerja dengan teman lainnya dan model pembelajaran ini dapat diterapkan di semua mata pelajaran. Dalam hal ini pengawasan guru pada saat diskusi menjadi hal yang penting, agar tercipta suasana belajar yang aktif, kreatif, dan menyenangkan. Dengan demikian, jelas bahwa melalui model pembelajaran Think Pair Share, siswa dapat secara langsung memahami suatu materisecara berkelompok dan saling membantu antar satu dengan yang lainnya, membuat kesimpulan (diskusi), serta mempresentasikan di depan kelas sebagai langkah evaluasi terhadap kegiatan pembelajaran yang telah dilakukan. Selain itu, model pembelajaran TPS yang berpasangan ini akan membuat siswa lebih berani mengungkapkan pendapatnya. Model ini 
juga mudah untuk digunakan sebab dapat mengefisienkan waktu dengan tidak mengatur tempat duduk siswa untuk membentuk kelompok.

Hartina (2008) berpendapat bahwa kelebihan model pembelajaran kooperatif think pair share sebagai berikut: (a) memungkinkan siswa untuk merumuskan dan mengajukan pertanyaan-pertanyaan mengenai materi yang diajarkan karena secara tidak langsung memperoleh contoh pertanyaan yang diajukan oleh guru, serta memperoleh kesempatan untuk memikirkan materi yang diajarkan; (b) siswa akan terlatih menerapkan konsep karena bertukar pendapat dan pemikiran dengan temannya untuk mendapatkan kesepakatan dalam memecahkan masalah; (c) siswa lebih aktif dalam pembelajaran karena menyelesaikantugasnya dalam kelompok, dimana tiap kelompok hanya terdiri dari 2 orang; (d) siswa memperoleh kesempatan untuk mempresentasikan hasil diskusinya dengan seluruh siswa sehingga ide yang ada menyebar; (e) memungkinkan guru untuk lebih banyak memantau siswa dalam proses pembelajaran

Model pembelajaran kooperatif tipe STAD (Student TeamsAchievement Devision) yang mempunyai lima komponen utama seperti presentasi kelas, tim kuis, skor kemajuan individual, rekognisi tim. Selain untuk membantu mahasiswa ke hal lebih bermakna, model pembelajaran think-pair-share (TPS) dan model pembelajaran kooperatif tipe STAD (Student Teams- Achievement Devision) yang disertai dengan penggunaan media VCD dan media gambar merupakan alternatif pembelajaran untuk memenuhi kebutuhan mahasiswa, sehingga dapat mengoptimalkan kemampuan, penalaran dan keterampilannya untuk meningkatkan hasil belajar mahasiswa pada mata kuliah senam lantai.

Berdasarkan penelitan yang telah dilakukan oleh (Eslamian \& Aref, 2012), model pembelajaran kooperatif merupakan salah satu komponen yang sangat penting dalam pencapaian kesuksesan akademik yang dapat meningkatkan hasil belajar, maka dari itu pembelajaran kooperatif saat ini dianggap sebagai model pembelajaran yang efektif dalam sistem pendidikan.

Chikmiyah (2012) menyatakan, pembelajaran kooperatif tipe Think-PairShare dapat memberikan pengetahuan dan hasil belajar siswa yang sangat signifikan berada pada level yang sangat tinggi. Model pembelajaran kooperatif tipe STAD (Student TeamsAchievement Devision) yang mempunyai lima komponen utama seperti presentasi kelas, tim kuis, skor kemajuan individual, rekognisi tim. Pembelajaran kooperatip tipe STAD merupakan salah satu tipe dari model pembelajaran kooperatif dengan menggunakan kelompok-kelompok kecil dengan jumlah anggota tiap kelompok 4-5 orang siswa secara heterogen (Trianto, 2007). (Slavin, 1990) menyebutkan bahwa "gagasan utama dari STAD adalah untuk memotivasi siswa supaya dapat saling mendukung dan membantu siswa lain dalam menguasai kemampuan yang diajarkan oleh guru".

Model STAD juga mempunyai beberapa kelebihan lain, menurut Soewarso (1998) kelebihan model STAD adalah sebagai berikut: a) 
Membantu siswa mempelajari isi materi pelajaran yang sedang dibahas. b) Adanya anggota kelompok lain yang menghindari kemungkinan siswa mendapatkan nilai rendah, karena dalam pengetesan lisan siswa dibantu oleh anggota kelompoknya. c) Menjadikan siswa mampu belajar berdebat, belajar mendengarkan pendapat orang lain, dan mencatat halhal yang bermanfaat untuk kepentingan bersama. d) Menghasilkan pencapaian belajar siswa yang tinggi serta menambah harga diri siswa dan memperbaiki hubungan dengan teman sebaya. e) Hadiah atau penghargaan yang diberikan akan memberikan dorongan bagi siswa untuk mencapai hasil yang lebih tinggi. f) Siswa yang lambat berpikir dapat dibantu untuk menambah ilmu pengetahuannya. g) Pembentukan kelompok-kelompok kecil memudahkan guru untuk memonitor siwa dalam belajar bekerja sama

$$
\text { Selain untuk membantu }
$$

mahasiswa ke hal lebih bermakna, model pembelajaran think-pair-share (TPS) dan model pembelajaran kooperatif tipe STAD (Student TeamsAchievement Devision) yang disertai dengan penggunaan media VCD dan media gambar merupakan alternatif pembelajaran untuk memenuhi kebutuhan mahasiswa, sehingga dapat mengoptimalkan kemampuan, penalaran dan keterampilannya untuk meningkatkan hasil belajar mahasiswa pada mata kuliah senam lantai.

Media pembelajaran yang dipilih diharapkan dapat mencakup aspek penglihatan (visual), pendengaran (auditif) dan gerak (motorik), karena selain bertujuan memudahkan peserta didik dalam belajar juga mampu menanamkan konsep. Semakin banyak indera, dan gerak mahasiswa yang terlibat dalam proses belajar semakin mudah mahasiswa belajar yang bermakna. Media pembelajaran yang populer digunakan dalam proses pembelajaran dengan menggunakan audio visual (Video Compact Disc/VCD) dan media gambar digunakan para guru/dosen sebagai pengguna media pembelajaran karena sifatnya dapat mengakses berbagai macam data dan fasilitas untuk memotivasi mahasiswa dalam belajar.

Kata "Media" berasal dari kata "Medium" yang berarti perantara atau pengantar dalam menyampaikan pesan komunikasi. Jadi media pembelajaran adalah segala bentuk perantara atau pengantar penyampaian pesan dalam proses komunikasi pembelajaran (Siddiq, Munawaroh, \& Sungkono, 2008).

Media Pembelajaran dapat dibedakan menurut kemampuannya membangkitkan rangsangan pada indra penglihatan, pendengaran, perabaan, penciuman dan pengecapan, sehingga secara umum ciri-ciri media pembelajaran adalah media itu dapat diraba, dilihat, didengar, dan diamati oleh panca indra (Angkowo \& Kosasih, 2007)

Romiszowski dalam (Angkowo \& Kosasih, 2007) media dikatakan sebagai " as the carriers on messages, from some transmitting source (which may be a human being or inanimate object), to receiver of the message (which in our case is the learner).

Longe (2012) menyatakan, media pembelajaran berupa VCD lebih efektif digunakan dalam pengajaran pengenalan listrik, yang diterapkan pada 
siswa sekolah-sekolah menengah pertama di Lagos State. Jadi, walaupun pada kenyataannya siswa tersebut berada di lokasi yang berbeda, dengan latar belakang budaya yang berbeda pula, media-media yang digunakan sebagai alat bantu pembelajaran dapat membantu siswa untuk memperoleh nilai yang lebih baik.

Mengacu pada permasalahan di atas, maka peneliti mencoba memberikan salah satu alternatif pemecahan masalah yaitu dengan penerapan model pembelajaran kooperatif tipe think-pair-share (TPS) dan tipe STAD (Student TeamsAchievement Devision), dimana model pembelajaran ini merupakan model pembelajaran dengan menggunakan sistem pengelompokan/ tim kecil yaitu antara dua sampai enam orang yang mempunyai latar belakang kemampuan akademik, jenis kelamin, ras atau suku yang berbeda (heterogen). Model pembelajaran ini efektif untuk membuat variasi suasana pola diskusi kelas, dimana mahasiswa diberikan waktu lebih banyak untuk berpikir, untuk merespon dan saling membantu satu sama lain dalam kelompok (Trianto, 2009).

Berdasarkan kajian konseptual tersebut di atas, tampaknya model pembelajaran yang berbantuan media pembelajaran merupakan salah satu bentuk model pembelajaran dalam perkuliahan praktik kemampuan dasar senam lantai yang layak untuk dikaji secara lebih mendalam dan ilmiah.

\section{METODE}

Penelitian ini bertujuan untuk
menguji pengaruh variabel-variabel bebas terhadap variabel terikat.
Penelitian ini menggunakan intake kelas mahasiswa sebagai sampel sehingga penelitian yang dilakukan adalah penelitian eksperimen kuasi (quasi eksperiment). Oleh sebab itu, tidak semua variabel (gejala yang muncul) dan kondisi eksperimen dapat dikontrol secara ketat.Quasi ekperimental design mempunyai kelompok kontrol, tetapi tidak dapat berfungsi sepenuhnya untuk mengontrol variabel-variabel luar yang mempengaruhi pelaksanaan eksperimen (Sugiyono, 2010). Rancangan penelitian ini menggunakan pretest-posttest non-equivalent control group design, yaitu desain penelitian eksperimen kuasi yang bertujuan untuk menyelidiki tingkat kesamaan antar kelompok dan skor pengetahuan awal berfungsi sebagai kovariat untuk melakukan kontrol secara statistik. Desain penelitian ini dapat disajikan pada Gambar berikut:

$\mathrm{O}_{1} \mathrm{X}_{1} \mathrm{Y}_{1} \mathrm{O}_{2}$

$\mathrm{O}_{3} \mathrm{X}_{1} \mathrm{Y}_{2} \mathrm{O}_{4}$

$\mathrm{O}_{5} \mathrm{X}_{2} \mathrm{Y}_{1} \mathrm{O}_{6}$

$\mathrm{O}_{7} \mathrm{X}_{2} \mathrm{Y}_{2} \mathrm{O}_{8}$

Gambar. Desain Penelitian "PretestPosttest Non-Equivalent Control Group Design" (Sugiyono, 2010)

Keterangan :

$\mathbf{O}_{1,3}=$ Observasi awal (pre-test) tentang hasil belajar senam lantai pada kelompok eksperimen

$\mathbf{O}_{2,4}=$ Observasi akhir (post-test) tentang hasil belajar senam lantai pada kelompok 


$$
\begin{aligned}
& \text { eksperimen } \\
& \mathbf{O}_{5,7}=\text { Observasi awal (pre-test) } \\
& \text { tentang hasil belajar senam } \\
& \text { lantai pada kelompok kontrol } \\
& \mathbf{O}_{6,8}=\text { Observasi akhir (post-test) } \\
& \text { tentang hasil belajar senam } \\
& \text { lantai pada kelompok kontrol } \\
& \mathrm{X}_{1}=\text { Model pembelajaran TPS } \\
& \mathrm{X}_{2}=\text { Model pembelajaran STAD } \\
& \mathrm{Y}_{1}=\text { Media Pembelajaran VCD } \\
& \mathrm{Y}_{2}=\text { Media Pembelajaran } \\
& \text { Gambar }
\end{aligned}
$$

Rancangan analisis data yang digunakan dalam penelitian ini adalah rancangan faktorial $2 \times 2$. Populasi dalam penelitian ini adalah mahasiswa Jurusan Pendidikan Jasmani, Kesehatan dan Rekreasi FOK Universitas Pendidikan Ganesha. Jumlah keseluruhan populasi adalah 156 mahasiswa. Pemilihan sampel yang digunakan sebagai kelas eksperimen dan kelas kontrol dilakukan dengan cara simple random sampling. Teknik ini digunakan sebagai teknik pengambilan sampel karena individuindividu pada populasi telah terdistribusi ke dalam kelas-kelas sehingga tidak mungkin untuk melakukan pengacakan individu dalam populasi. Sehingga setiap kelas mendapat kesempatan yang sama untuk dijadikan anggota sampel.

Pengambilan sampel dilakukan dalam dua tahap. Tahap pertama dalam pemilihan sampel, peneliti menggunakan teknik undian di mana kelas yang muncul dalam undian digunakan sebagai kelas sampel. Kelaskelas tersebut antara lain IIA, IIB, IIC, IID, IIE dan IIF. Dari ke enam kelas ini akan dilakukan Randomisasi agar mendapatkan sampel empat kelas. Selanjutnya dari empat kelas tersebut dirandom lagi untuk menentukan dua kelas yang menggunakan model pembelajaran TPS berbantuan media VCD dan dua kelas menggunakan model STAD berbantuan media gambar (kelompok kontrol). Berdasarkan teknik tersebut akan diperoleh kelompok sampel yang memiliki kesetaraan dan homogenitas yang tinggi.

Penelitian ini meneliti tiga variabel yang terdiri dari dua variabel bebas dan variabel terikat. (1) Model pembelajaran kooperatif tipe TPS dan STAD, (2) Media pembelajaran VCD dan media gambar sebagai variabel bebas kedua yang mempengaruhi keberhasilan perlakuan, dan (3) hasil belajar sebagai variabel terikat.

Penelitian eksperimen ini dilaksanakan melalui beberapa tahapan. Tahap pertama, menyusun rubrik kinerja hasil belajar kemampuan dasar senam lantai dan format asessmen penilaian psikomotor Roll depan dan Back Roll. Serta sudah mendapatkan pemeriksaan dari dua orang penilai (judges). Tahap kedua, uji coba tes psikomotor senam lantai dan tes hasil belajar senam lantai. Tahap Ketiga, tahap pelaksanaan eksperimen yang dilakukan dengan melaksanakan pembelajaran pada siswa kelompok eksperimen dan kelompok kontrol sesuai dengan rencana pembelajaran yang telah disusun.

Pembelajaran pada kelompok eksperimen menggunakan model pembelajaran kooperatif tipe Think-PairShare (TPS), menggunakan media VCD dan pembelajaran TPS berbantuan VCD sedangkan pembelajaran pada mahasiswa kelompok kontrol menggunakan model pembelajaran kooperatif STAD, menggunakan media 
gambar dan pembelajaran STAD dengan berbantuan media gambar. Selanjutnya dilakukan dengan memberikan tes hasil belajar kemampuan dasar senam lantai baik pada kelompok eksperimen maupun kelompok kontrol untuk mendapatkan data tentang hasil belajar psikomotor kemampuan dasar senam lantai mahasiswa pada kedua kelompok tersebut.

Metode analisis data penelitian ini menggunakan analisis kovarian (ANACOVA) faktorial $2 \times 2$. Analisis kovarian ini digunakan untuk menguji hipotesis pertama, kedua, dan ketiga. Metode ANACOVA digunakan untuk mengetahui ada dan tidaknya pengaruh model dan media pembelajaran terhadap hasil belajar kemampuan dasar senam lantai. Untuk menguji hipotesis penelitian, digunakan analisis kovarian faktorial $2 \times 2$ dengan bantuan SPSS 16.0 for windows. Rancangan faktorial $2 \times 2$ adalah suatu metode analisis untuk menyelidiki secara serempak pengaruh dua variabel

HASIL DAN PEMBAHASAN

Tabel 1 Uji Hipotesis

\begin{tabular}{cccccc}
\hline Source & $\begin{array}{c}\text { Type III Sum of } \\
\text { Squares }\end{array}$ & df & $\begin{array}{c}\text { Mean } \\
\text { Square }\end{array}$ & F & Sig. \\
\hline Corrected Model & $756.024^{\mathrm{a}}$ & 4 & 189.006 & 64.052 & .000 \\
Intercept & 2.975 & 1 & 2.975 & 1.008 & .318 \\
X & 260.216 & 1 & 260.216 & 88.185 & .000 \\
A & 191.228 & 1 & 191.228 & 64.805 & .000 \\
B & 155.144 & 1 & 155.144 & 52.577 & .000 \\
A * B & 22.220 & 1 & 22.220 & 7.530 & .007 \\
Error & 292.130 & 99 & 2.951 & & \\
Total & 56988.000 & 104 & & & \\
\hline Corrected Total & 1048.154 & 103 & & & \\
\hline
\end{tabular}


Berdasarkan Tabel 1, maka pengujian hipotesis ditemukan:

Hasil uji hipotesis pertama telah berhasil menerima $\mathrm{H} 1$, yang berarti bahwa ada perbedaan yang signifikan hasil belajar kemampuan dasar senam lantai antara mahasiswa yang mengikuti model pembelajaran TPS dengan model STAD pada Mahasiswa semester II Jurusan Penjaskesrek fakultas Olahraga dan Kesehatan Undiksha. Rerata skor hasil belajar kemampuan dasar senam lantai mahasiswa yang mengikuti model pembelajaran TPS adalah 24.94 dan rerata skor hasil belajar kemampuan dasar senam lantai mahasiswa yang mengikuti model pembelajaran STAD adalah 21.44, sehingga secara keseluruhan hasil belajar kemampuan dasar senam lantai mahasiswa yang mengikuti model pembelajaran TPS lebih baik dari model pembelajaran STAD. Hasil analisis varian menunjukkan bahwa Fhitung bahwa lebih besar dari pada Ftabel ( $F=64.805$ dengan $\mathrm{P}<0,05)$. Hal ini berarti bahwa terdapat perbedaan hasil belajar kemampuan dasar senam lantai antara mahasiswa yang mengikuti model pembelajaran TPS dengan yang mengikuti model pembelajaran STAD, dinyatakan diterima.

Hasil uji hipotesis tersebut menunjukkan bahwa model pembelajaran TPS lebih unggul dalam meningkatkan hasil belajar kemampuan dasar senam lantai dari pada model pembelajaran STAD. Keunggulan model pembelajaran TPS juga dibuktikan (dengan penelitian yang dilakukan oleh Chikmiyah dan Sugiarto (2012), dalam penelitiannya di temukan bahwa hasil belajar siswa melalui model pembelajaran kooperatif Tipe Think Pair
Share menunjukan bahwa terdapat hubungan yang sangat kuat antara pengetahuan metakognitif dan hasil belajar. Hasil penelitian ini konsisten dengan penelitian Tristiantari, Marhaeni, \& Koyan (2013) menyatakan bahwa siswa yang mengikuti model pembelajaran kooperatif tipe TPS mampu meningkatkan keterampilan berpikir kreatif siswa.

Di sisi lain, model pembelajaran TPS merupakan suatu proses pembelajaran yang diawali oleh suatu pengamatan seorang model. Dengan melakukan pengamatan, maka mahasiswa akan memperoleh gambaran yang jelas dan akurat terhadap konsep gerak yang akan dilakukan. Pengamatan akan secara langsung menjadi sebuah proses mengingat, sehingga sangat bermanfaat dalam melakukan gerakan. Jadi, model secara langsung merupakan fungsi penguat, karena model berasal dari seorang yang ahli, bahkan seorang atlet professional pada bidang yang sedang diajarkan, seperti misalnya atlet senam lantai. Dengan berbekal ingatan yang diperkuat dengan peran model maka dimungkinkan seorang pebelajar akan lebih fokus, berkonsentrasi, tertarik dan memiliki semangat tinggi untuk belajar. Pembelajaran TPS juga menekankan pada pembelajaran yang berpusat pada mahasiswa (student center). Hal ini terbukti dengan tahapan dalam pembelajaran TPS dimana mahasiswa dapat mempunyai banyak waktu untuk berpikir, untuk merespon dan saling membantu. Pada tahap retensi, mahasiswa dibebaskan untuk melakukan konsep berpikir dan mengingat serta membanyangkan secara seluas-luasnya baik individu 
maupun kelompok berdasarkan apa yang telah diamati dari model. Dengan keleluasaan ini, mahasiswa secara aktif berpikir dan berperilaku sesuai dengan kebutuhanya sehingga meningkatkan transfer mengingatnya ke dalam fase gerakan, sedangkan pada tahap produksi, mahasiswa diberikan keluasaan untuk melakukan latihan dan mempraktekkan secara seluas-luasnya gerakan yang telah diingat dan diamati, sehingga secara konseptual mahasiswa terpola hasil gerakannya dari mengamati, mengingat dan mempraktekkan. Dengan pola ini maka dimungkinkan hasil belajar gerak dalam senam lantai memungkinkan untuk lebih berhasil dalam penguasaannya. Pola yang terjadi pada model pembelajaran TPS belum tentu dapat terjadi dalam model STAD sehingga cukup masuk diakal jika dalam pembelajaran kemampuan dasar senam lantai lebih baik hasilnya dengan menggunakan model pembelajaran TPS dibandingkan dengan model pembelajaran STAD.

Hasil uji hipotesis kedua telah berhasil menerima $\mathrm{H} 1$, yang berarti bahwa ada perbedaan yang signifikan hasil belajar kemampuan dasar senam lantai antara mahasiswa yang mengikuti media pembelajaran VCD dengan media pembelajaran gambar pada Mahasiswa semester II Jurusan Penjaskesrek fakultas Olahraga dan Kesehatan Undiksha. Rerata skor hasil belajar kemampuan dasar senam lantai mahasiswa yang mengikuti media pembelajaran VCD adalah 24.48 dan rerata skor hasil belajar kemampuan dasar senam lantai mahasiswa yang mengikuti media pembelajaran gambar adalah 21.90, sehingga secara keseluruhan hasil belajar kemampuan dasar senam lantai mahasiswa yang mengikuti media pembelajaran VCD lebih baik dari model pembelajaran gambar. Hasil analisis varian menunjukkan bahwa Fhitung lebih besar daripada Ftabel ( $F=52.577$ dengan $p<0,05)$. Hal ini berarti bahwa terdapat perbedaan hasil belajar kemampuan dasar senam lantai antara mahasiswa yang mengikuti media pembelajaran VCD dengan yang mengikuti media pembelajaran gambar, dinyatakan diterima.

Hasil uji hipotesis tersebut menunjukkan bahwa media pembelajaran VCD lebih unggul dalam meningkatkan hasil belajar kemampuan dasar senam lantai dari pada media pembelajaran gambar. Keunggulan media pembelajaran VCD juga dibuktikan (dengan penelitian yang dilakukan oleh Longe), yang menunjukkan bahwa media pembelajaran VCD lebih efektif digunakan di dalam pembelajaran, yang diterapkan pada siswa sekolah-sekolah menengah pertama di Lagos State. Demikian pula hasil penelitian telah menemukan manfaat dari penggunaan VCD dalam pembelajaran. VCD memberi dampak yang signifikan pada proses pembelajaran, khususnya dalam praktik. VCD merupakan audio visual yang dimana pemaparan melalui suara dianggap sebagai faktor pendukung, bukan merupakan satu faktor utama.

Berdasarkan uraian di atas, maka kemampuan dasar senam lantai mahasiswa yang mengikuti media pembelajaran VCD lebih baik dibandingkan dengan mahasiswa yang mengikuti media pembelajaran gambar. Hasil penelitian ini konsisten dengan penelitian Cirtha (2012), yang 
menyatakan bahwa penerapan model pembelajaran kooperatif berbantuan CD interaktif mampu meningkatkan hasil belajar mahasiswa.

Hasil uji hipotesis ketiga telah berhasil menerima $\mathrm{H} 1$ yang menyatakan bahwa terdapat pengaruh interaktif antara media pembelajaran dengan model pembelajaran terhadap hasil belajar kemampuan dasar senam lantai mahasiswa jurusan penjasorkes semester II Fakultas Olahraga dan Kesehatan Undiksha. Hasil uji mengindikasikan terdapat pengaruh interaktif antara media dan model pembelajaran terhadap hasil belajar kemampuan dasar senam lantai yang dipertegas oleh analisis kovarian (ANAKOVA) faktorial $2 \times 2$ menunjukkan bahwa pada pengaruh interaktif antara model dan media pembelajaran terhadap hasil belajar kemampuan dasar senam lantai tampak nilai statistik $F=88.185$ dengan angka signifikansi 0.001 . Angka signifikansi ini lebih kecil dari $0.05(F=88.185$ dengan $p<0,05)$. Hal ini berarti bahwa terdapat pengaruh interaktif antara model dan media pembelajaran terhadap hasil belajar kemampuan dasar senam lantai. Berdasarkan hasil analisis tersebut, maka model dan media pembelajaran memang benar mempengaruhi hasil belajar kemampuan dasar senam lantai secara signifikan setelah dilakukan pengendalian variabel pengetahuan awal telah dikendalikan. Hasil penelitian ini juga diperkuat oleh penelitian yang dilakukan oleh Chikmiyah dan Sugiarto (2012), menunjukkan bahwa model pembelajaran kooperatif tipe TPS menunjukkan bahwa terdapat hubungan yang sangat kuat antara pengetahuan metakognitif dan hasil belajar. Penelitian
Tristiantari (2013) menyatakan bahwa siswa yang mengikuti model pembelajaran kooperatif tipe TPS mampu meningkatkan keterampilan berpikir kreatif siswa. Penelitian yang dilakukan oleh Perdy Karuru juga menyatakan bahwa hasil belajar yang diajar dengan pendekatan keterampilan proses dalam seting pembelajaran kooperatif STAD lebih baik dibanding pembelajaran yang tidak menggunakan pembelajran kooperatif. Begitu juga dengan penelitian tentang media pembelajaran yang dilakukan oleh Longe yang menunjukkan bahwa media pembelajaran VCD lebih efektif digunakan di dalam pembelajaran, yang diterapkan pada siswa sekolah menengah pertama di Lagos State. Demikian pula hasil penelitian telah menemukan manfaat dari penggunaan VCD dalam pembelajaran (AjayiDopemu, 1990, Osasona, 1990 \& Dietrich, 1975) yang menyatakan bahwa VCD memberi dampak yang signifikan pada proses pembelajaran, khususnya dalam praktik. Penelitian ini juga diperkuat oleh penelitian Parwata (2007), yang menyatakan bahwa penerapan model pembelajaran langsung berbantuan VCD dapat meningkatkan aktivitas dan hasil belajar mahasiswa pada perkuliahan atletik I, dimana mahasiswa memberikan respon yang positif terhadap penerapan model pembelajaran langsung berbantuan VCD.

Penelitian ini membuktikan bahwa model dan media pembelajaran mempunyai kesamaan yang sangat efektif untuk meningkatkan hasil belajar kemampuan dasar senam lantai. Berdasarkan hal tersebut maka implikasi yang dapat diberikan adalah sebagai 
berikut. Pertama, keefektifan proses pembelajaran menggunakan model dan media pembelajaran dalam meningkatkan hasil belajar kemampuan dasar senam lantai dapat didukung dengan memperhatikan dan membangkitkan motivasi belajar mahasiswa. Kedua, model dan media pembelajaran merupakan kondisi yang sesuai bagi mahasiswa untuk meningkatkan hasil belajar kemampuan dasar senam lantai. Ketiga, penerapan model dan media pembelajaran akan merangsang mahasiswa yang memiliki hasil belajar rendah untuk terlibat aktif di dalam memecahkan permasalahn belajar dan meningkatkan hasil belajarnya. Berdasarkan hasil statistik rerata dengan bantuan program SPSS 16.0 for Windows untuk hasil belajar kemampuan dasar senam lantai, ditunjukkan di dalam Gambar 1.

Terkait dengan hasil uji pengaruh interaksi antara model dan media pembelajaran terhadap hasil belajar kemampuan dasar senam lantai, maka perlu dilakukan uji analisis lanjut.Uji lanjut ini bertujuan untuk meyakinkan apakah perbedaan skor rata-rata keempat kelompok perlakuan berbeda nyata secara perhitungan statistik. Keempat kelompok perlakuan tersebut adalah (1) model pembelajaran TPS berbantuan VCD (TPSVCD), (2) model pembelajaran TPS berbantuan media Gambar (TPSMG), (3) model pembelajaran STAD berbantuan VCD (STADVCD), (4) model pembelajaran STAD berbantuan media Gambar (STADMG). Uji analisis lanjut dilakukan dengan Post Hoc Test menggunakan Least Significant Difference (LSD). Hasil uji lanjut ini disajikan pada Tabel 2.

Gambar 1. Profil interaksi antara model dan media pembelajaran terhadap hasil belajar kemampuan dasar senam lantai.

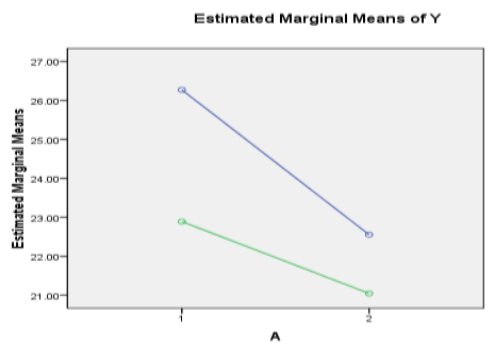

Tabel 2. Hasil Analisis Uji Lanjut Perbedaan Nilai Rata-Rata Hasil Belajar

\begin{tabular}{|c|c|c|c|c|c|c|}
\hline \multirow{2}{*}{ (I) Model } & \multirow{2}{*}{ (J) Model } & \multirow{2}{*}{$\begin{array}{c}\text { Mean } \\
\text { Difference } \\
(\mathrm{I}-\mathrm{J})\end{array}$} & \multirow{2}{*}{ Std. Error } & \multirow{2}{*}{ Sig. } & \multicolumn{2}{|c|}{$\begin{array}{c}\text { 95\% Confidence } \\
\text { Interval }\end{array}$} \\
\hline & & & & & $\begin{array}{l}\text { Lower } \\
\text { Bound }\end{array}$ & $\begin{array}{l}\text { Upper } \\
\text { Bound }\end{array}$ \\
\hline \multirow{3}{*}{$\begin{array}{l}\text { TPS } \\
\text { VCD }\end{array}$} & TPSMG & $3.0000^{*}$ & .65183 & 0.000 & 1.7068 & 4.2932 \\
\hline & $\begin{array}{l}\text { STAD } \\
\text { VCD }\end{array}$ & $3.9231^{*}$ & .65183 & 0.000 & 2.6299 & 5.2163 \\
\hline & STADMG & $6.0769^{*}$ & .65183 & 0.000 & 4.7837 & 7.3701 \\
\hline \multirow[t]{2}{*}{ TPSMG } & $\begin{array}{l}\text { TPS } \\
\text { VCD }\end{array}$ & $-3.0000^{\star}$ & .65183 & 0.000 & -4.2932 & -1.7068 \\
\hline & $\begin{array}{l}\text { STAD } \\
\text { VCD }\end{array}$ & .9231 & .65183 & 0.160 & -.3701 & 2.2163 \\
\hline
\end{tabular}




\begin{tabular}{|c|c|c|c|c|c|c|}
\hline \multirow{2}{*}{ (I) Model } & \multirow{2}{*}{ (J) Model } & \multirow{2}{*}{$\begin{array}{c}\text { Mean } \\
\text { Difference } \\
(\mathrm{I}-\mathrm{J})\end{array}$} & \multirow{2}{*}{ Std. Error } & \multirow{2}{*}{ Sig. } & \multicolumn{2}{|c|}{$\begin{array}{c}\text { 95\% Confidence } \\
\text { Interval }\end{array}$} \\
\hline & & & & & $\begin{array}{l}\text { Lower } \\
\text { Bound }\end{array}$ & $\begin{array}{l}\text { Upper } \\
\text { Bound }\end{array}$ \\
\hline & STADMG & $3.0769^{*}$ & .65183 & 0.000 & 1.7837 & 4.3701 \\
\hline \multirow[t]{3}{*}{$\begin{array}{l}\text { STAD } \\
\text { VCD }\end{array}$} & $\begin{array}{l}\text { TPS } \\
\text { VCD }\end{array}$ & $-3.9231^{*}$ & .65183 & 0.000 & -5.2163 & -2.6299 \\
\hline & TPSMG & -.9231 & .65183 & 0.160 & -2.2163 & .3701 \\
\hline & STADMG & $2.1538^{*}$ & .65183 & 0.001 & .8606 & 3.4471 \\
\hline \multirow[t]{3}{*}{ STADMG } & $\begin{array}{l}\text { TPS } \\
\text { VCD }\end{array}$ & $-6.0769^{*}$ & .65183 & 0.000 & -7.3701 & -4.7837 \\
\hline & TPSMG & $-3.0769^{*}$ & .65183 & 0.000 & -4.3701 & -1.7837 \\
\hline & $\begin{array}{l}\text { STAD } \\
\text { VCD }\end{array}$ & $-2.1538^{*}$ & .65183 & 0.001 & -3.4471 & -.8606 \\
\hline
\end{tabular}

Berdasarkan Tabel 1, dapat disampaikan secara signifikan ada perbedaan mean difference hasil belajar antara perlakuan TPSVCD dan TPSMG, antara TPSVCD dan STADVCD, antara TPSVCD dan STADMG. Dengan demikian, dapat diinterpretasikan bahwa interaksi antara model pembelajaran TPS berbantuan VCD memberikan pengaruh yang paling baik terhadap hasil belajar kemampuan dasar senam lantai. Selanjutnya secara berturut-turut diikuti oleh interaksi antara model pembelajaran TPS berbantuan media Gambar dan interaksi antara model pembelajaran STAD berbantuan media VCD, dan terakhir interaksi antara model pembelajaran STAD berbantuan media Gambar.

\section{SIMPULAN DAN SARAN}

Mengacu pada rumusan masalah, analisis data dan pembahasan dapat disimpulkan beberapa hal sebagai berikut. Pertama, terdapat perbedaan hasil belajar kemampuan dasar senam lantai antara mahasiswa yang mengikuti model pembelajaran Think-Pair-Share
(TPS) dengan mahasiswa yang mengikuti model pembelajaran Kooperatif tipe STAD (Student TeamsAchievement Devision). Perhitungan dengan ANAVA dua jalur menghasilkan nilai Fhitung $=64.805$; sedangkan $p=$ 0.001 . Ini berarti, nilai Fhitung lebih besar dari pada $F_{\text {tabel }}(F=64.805$ dengan $\mathrm{p}<0,05)$. Kedua terdapat perbedaan hasil kemampuan dasar senam lantai antara mahasiswa yang belajar dengan media VCD dan media gambar. Jika dilakukan perhitungan dengan analisis kovarian (ANAKOVA) faktorial $2 \times 2$ nilai Fhitung $=52.577$; sedangkan $\mathrm{P}=0.001$. Ini berarti, nilai Fhitung lebih besar daripada $F_{\text {tabel }}(F=52.577$ dengan $\mathrm{p}<0,05)$. Ketiga terdapat pengaruh interaktif antara model dan media pembelajaran terhadap hasil belajar kemampuan dasar senam lantai pada mahasiswa Penjaskesrek. Indikasi ini dipertegas oleh hasil uji analisis kovarian (ANAKOVA) faktorial $2 \times 2$ yang menghasilkan nilai Fhitung $=88.185$ sedangan $p=0.001$, taraf signifikan $5 \%$. Ini berarti, nilai $F_{\text {hitung }}$ lebih besar dari pada $F_{\text {tabel }}(F=88,185$ dengan $P<0,05)$. 
Hasil ini menunjukkan terdapatnya pengaruh interaktif yang signifikan antara media dan model pembelajaran terhadap hasil belajar kemampuan dasar senam lantai setelah dilakukan pengendalian variabel pengetahuan awal telah dikendalikan.

Berdasarkan kesimpulan di atas, dalam upaya meningkatkan hasil belajar kemampuan dasar senam lantai maka dapat disarankan sebagai berikut. Kepada pemegang kebijakan, diharapkan untuk mempertimbangkan model pembelajaran TPS dan media pembelajaran VCD ini, sebagai acuan dalam menerapkan pembelajaran penjasorkes di lingkup perguruan tinggi maupun sekolah. Kepada dosen-dosen ataupun pendidik lainnya khususnya pendidik di bidang penjasorkes diharapkan dapat menerapkan model pembelajaran TPS dengan berbantuan media VCD dengan menggunakan masalah-masalah yang ada di bidang penjasorkes sebagai bahan dalam menyusun program pembelajaran. Kepada mahasiswa ataupun siswa, diharapkan untuk meningkatkan kemampuan fisik guna menunjang pembelajaran penjasorkes dan yang lainnya sehingga hasil belajar yang diperoleh dapat lebih baik. Untuk lebih meyakinkan temuan-temuan dalam penelitian ini serta keefektifan model dan media pembelajaran, diperlukan kajian yang lebih mendalam dengan melakukan penelitian pada bidang yang lain dan skala yang lebih luas.

\section{DAFTAR PUSTAKA}

Angkowo, R., \& Kosasih, A. (2007). Optimalisasi media pembelajaran. Gramedia Widiasarana.

Chikmiyah, C. (2012). Relationship between metacognitive knowledge and student learning outcomes through cooperative learning model type think pair share on buffer solution matter. Unesa Journal of Chemical Education, 1(1).

Cirtha, I. W. (2012). Peningkatan Hasil Belajar IPA Siswa Kelas VI dengan Penerapan Pembelajaran Kontekstual Berbantuan Media CD Interaktif Dilengkapi Bahasa Isyarat di SLB-b Negeri Singaraja. Jurnal Teknologi Pembelajaran Indonesia, 1(1).

Eslamian, D., \& Aref, K. (2012). The influence of cooperative learning on academic performance. Journal of American Science, 8(2), 200-203.

Husdarta, H. J. S. (2009). Manajemen pendidikan jasmani. Bandung: Alfabeta.

Isjoni, H. (2009). Pembelajaran kooperatif. Yogyakarta: Pustaka Pelajar.

Lie, A. (2002). Cooperative learning: Mempraktikkan cooperative learning di ruang-ruang kelas. Jakarta: Grasindo.

Longe, I. M. (2012). Effects of video compact disc (VCD) based instructions on students' learning outcomes in an introductory technology class in nigerian secondary schools. African Journal of Computing \& ICT, 5(4), 69-72.

Siddiq, M. D., Munawaroh, I., \& Sungkono. (2008). Pengembangan Bahan Pembelajaran SD. Direktorat Jenderal Pendidikan Tinggi, Depdiknas, Jakarta.

Slavin, R. E. (1990). Cooperative learning: Theory, research, and practice. Prentice-Hall,.

Sugiyono. (2010). Metode penelitian 
kuantitatif kualitatif dan $R \& D$. Bandung: Alfabeta.

Thobroni, M., \& Mustofa, A. (2011). Belajar dan pembelajaran. Jogjakarta: Ar-Ruzz Media.

Trianto. (2007). Model-model pembelajaran inovatif berorientasi Konstruktivistik. Jakarta: Prestasi Pustaka.

Trianto. (2009). Mendesain Model Pembelajaran Inovatif-Progresif. Jakarta: Kencana.

Trianto. (2010). Mendesain Model Pembelajaran Inovatif-Progresif: Konsep, Landasan dan Implementasinya pada kurikulum Tingkat Satuan Pendidikan (KTSP). Jakarta: Kencana.

Tristiantari, N. K. D., Marhaeni, A., \& Koyan, I. W. (2013). Pengaruh Implementasi Model Pembelajaran Kooperatif Tipe Tps Terhadap Kemampuan Berbicara Dan Keterampilan Berpikir Kreatif Pada Siswa Kelas V SD Negeri Gugus III Kecamatan Seririt. PENDASI:
Jurnal Pendidikan Dasar Indonesia, 3(1). 